\title{
ANALISIS PENGARUH PENERAPAN GOOD CORPORATE GOVERNANCE DAN RENCANA STRATEGIS TERHADAP PENINGKATAN KINERJA UNIT INTERNAL AUDIT \& CONTROL PT. GMF AERO ASIA
}

\author{
Dewi Nari Ratih Permada *)
}

*)dosen universitas pamulang, email : dewi.permada@gmail.com

ARTICLES

INFORMATION

\section{JURNAL SEKURITAS}

(Saham, Ekonomi, Keuangan dan Investasi )

Vol.1, No. 3, Maret 2018 Halaman : 46-69

(c) LPPM \& Prodi Manajemen UNVERSITAS PAMULANG

ISSN (online) : 2581-2777 ISSN (print) : :2581-2696

Keyword :

Good Corporate

Governance, rencana strategis, dan Kinerja Unit Internal Audit \& Control

JEL. classification :

D79, E32, G30, M20

\section{Contact Author :}

PRODI MANAJEMEN UNPAM

JL.Surya Kencana No.1 Pamulang

Tangerang Selatan - Banten

Telp. (021) 7412566, Fax (021) 7412491 Email :

jurnalfinance.unpam@gmail.com
Penelitian ini bertujuan untuk menganalisa penerapan Good Corporate Governance dan rencana strategis tersebut untuk peningkatan kinerja Unit Internal Audit \& Control GMF Aero Asia Penelitian ini menggunakan metode penelitian kuantitatif studi korelasional. Instrumen pengumpul data yang digunakan adalah kuesioner dengan skala likert. Jumlah populasi sebanyak 69 pegawai dari 4 unit yaitu Unit Internal Audit \& Control, Unit Accounting and Treasury, Unit Corporate Secretary dan Unit Corporate Development.

Data yang diperoleh dari penelitian ini telah dianalisis dengan menggunakan metode statistik dengan menggunakan program SPSS versi 20.0. Dari hasil penelitian dan analisis ini menunjukan bahwa :

1. Terdapat pengaruh yang positif dan signifikan antara variabel Good Corporate Governance

2. Terdapat pengaruh yang positif dan signifikan antara variabel rencana strategis

3. Terdapat pengaruh yang positif dan signifikan antara variabel Good Corporate Governance dan rencana strategis terhadap kinerja Unit Internal Audit \& Control

Effect Analysis of Good Corporate Governance and Strategic Plan Against Improvement of Performance on Internal Audit \& Control Unit. This research uses quantitative research methods correlational study. Data collection instrument used was a questionnaire with Likert scale. Total population of as many as 69 employees of four units: Unit Internal Audit \& Control, Unit Accounting and Treasury, Unit Corporate Secretary and Unit Corporate Development.

Data obtained from this study have been analyzed using statistical methods using SPSS version 20.0. From the results of research and analysis shows that:

1. There is a positive and significant effect among variables of Good Corporate Governance

2. There is a positive and significant impact among strategic plan variables

3. There is a positive and significant effect among variables of Good Corporate Governance and strategic plan on the performance of Internal Audit \& Control Unit 


\section{A. Pendahuluan}

PT. Garuda Maintenance Facility (GMF) Aero Asia merupakan anak perusahaan PT Garuda Indonesia, salah satu perusahaan penerbangan milik pemerintah Republik Indonesia. GMF Aero Asia didirikan untuk menjadi salah satu aircraft maintenance solutions provider terbaik di dunia, yang memiliki reputasi dalam quality, reliability, on-time delivery and affordability.

Bisnis utama GMF Aero Asia adalah penyediaan jasa perawatan dan perbaikan pesawat terbang yang mencakup rangka pesawat, mesin, komponen dan jasa pendukung lainnya secara terintegrasi atau dikenal dengan bisnis Maintenance, Repair And Overhaul (MRO).

Visi GMF Aero Asia adalah menjadi MRO kelas dunia pilihan customer. Saat ini GMF Aero Asia telah memasuki tahap kedua dari program Global Challenge setelah melewati tahap pertama dan mempersiapkan landasan yang kokoh untuk tahap berikutnya.

Sedangkan misi GMF Aero Asia adalah menyediakan solusi Maintanance Repair \& Overhoul (MRO) yang terintegrasi dan handal untuk keamanan udara dan menjamin kualitas hidup manusia.

GMF Aero Asia telah menerapkan nilai Good Corporate Governance sejak ditetapkan tanggal 23 Juni 2006 yang merupakan penjabaran lebih lanjut dari nilai-nilai yang terkandung di dalam Pedoman Kebijakan Perusahaan (PKP) khususnya yang terkait dengan Good Corporate Governance yang disusun dengan mengacu pada Pedoman Good Corporate Governance yang disusun oleh Komite Nasional Kebijakan Corporate Governance.

Peran semua stakeholder membuat pelaksanaan Good Corporate Governance sangat mungkin dilaksanakan. Penilaian dari asesor eksternal, Badan Pengawasan Keuangan dan Pembangunan (BPKP) terhadap GMF Aero Asia menghasilkan skor 87,41 tahun 2011 yang lebih baik dari tahun 2010 menunjukkan perusahaan ini sangat serius melaksankan Good Corporate Governance guna lebih meningkatkan kinerja perusahaan secara keseluruhan.

Rencana strategis (renstra) yang dimiliki Audit internal \& Control GMF Aero Asia periode 2011 sampai dengan 2015 dengan misinya membuat tata kelola yang bersih untuk keuntungan perusahaan melalui perlindungan risiko audit \& pengendalian fasilitasi.

Rencana strategis Audit internal \& Control GMF Aero Asia berkesinambungan untuk periode 2011 sampai dengan 2015 mulai dari mapping, change, development, established, dan sustained. Program tahun 2011 antara lain : internal control development, audit plan execute, campaign ERM, people development $150 \%$ certified), Review BSC (Balance Score Card). Program tahun 2012 antara lain : New IA BSC, develop IC, comprehensive indicator - BSC, implemented ERM framework, reduce FCAR open, set up WBS policy, people development $(75 \%+3$ int'l certificate).

\section{B. Perumusan Masalah}

1. Apakah terdapat pengaruh positif dan signifikan antara Good Corporate Governance terhadap kinerja Unit Internal Audit \& Control GMF Aero Asia?

Jurnal Sekuritas, Vol.1, No.3, Maret 2018 
2. Apakah terdapat pengaruh positif dan signifikan antara rencana strategis terhadap kinerja Unit Internal Audit \& Control GMF Aero Asia?

3. Apakah terdapat pengaruh positif dan signifikan antara Good Corporate Governance dan renstra secara simultan terhadap kinerja Unit Internal Audit \& Control GMF Aero Asia"

\section{Tujuan Penelitian}

1. Adapun hasil penelitian dari penerapan Good Corporate Governance dan rencana strategis tersebut adalah untuk peningkatan kinerja Unit Internal Audit \& Control GMF Aero Asia melalui prinsip keterbukaan, akuntabilitas, dapat dipercaya, bertanggungjawab dan adil serta pemantauan manajemen terhadap visi dan misi yang ada, berdasarkan peraturan yang berlaku

2. Implementasi penerapan Good Corporate Governance akan mendorong tumbuhnya mekanisme check and balance di lingkungan manajemen khususnya dalam memberi perhatian kepada stakeholder dan mitra kerja

3. Menyakini bahwa penerapan Good Corporate Governance untuk memberikan nilai tambah bagi semua pihak yang berkepentingan (stakeholder) dan meningkatkan daya saing perusahaan di antara perusahaan sejenis di kawasan Asia bahkan dunia

\section{Tinjauan Teori}

\section{Good Corporate Governance (GCG)}

Cadbury Committee pada tahun 1992 mengemukakan bahwa Corporate Governance diartikan sebagai sistem yang berfungsi untuk mengarahkan dan mengendalikan perusahaan. Sementara Forum of Corporate Governance for Indonesia-FCGI (2001) mengemukakan bahwa Corporate Governance adalah seperangkat peraturan yang mengatur hubungan (dengan kata lain sebagai sistem yang mengendalikan perusahaan) antara pemegang saham, pengurus (pengelola) perusahaan, pihak kreditur, pemerintah, karyawan serta pemegang kepentingan internal dan eksternal lainnya yang berkaitan dengan hak-hak dan kewajiban mereka.

Good Corporate Governance (GCG) secara definitif merupakan sistem yang mengatur dan mengendalikan perusahaan yang menciptakan nilai tambah (value added) untuk semua stakeholder (Monks, 2003). Ada dua hal yang ditekankan dalam konsep ini, pertama, pentingnya hak pemegang saham untuk memperoleh informasi dengan benar dan tepat pada waktunya dan, kedua, kewajiban perusahaan untuk melakukan pengungkapan (disclosure) secara akurat, tepat waktu, transparan terhadap semua informasi kinerja perusahaan, kepemilikan, dan stakeholder.

Pedoman Umum Good Corporate Governance di-Indonesiakan disusun oleh Komite Nasional Kebijakan Governance (KNKG). Pedoman yang diterbitkan pada tahun 2006 ini merupakan revisi atas Pedoman Good Corporate Governance yang diterbitkan pada tahun 2001. Meskipun Pedoman Umum Good Corporate Governance Indonesia 2006 ini tidak memiliki kekuatan hukum yang mengikat, namun dapat menjadi rujukan bagi dunia usaha dalam menerapkan Good Corporate Governance.

Esensi dari Corporate Governance adalah peningkatan kinerja perusahaan melalui supervisi atau pemantauan kinerja manajemen serta adanya akuntabilitas manajemen terhadap pihak-pihak yang berkepentingan lainnya, berdasarkan 
kerangka aturan dan peraturan yang berlaku. Secara umum terdapat 5 (lima) prinsip dasar dari Good Corporate Governance, yaitu :

a. Transparansi/ transparency (keterbukaan informasi), yaitu keterbukaan dalam melaksanakan proses pengambilan keputusan dan keterbukaan dalam mengemukakan informasi materiil dan relevan mengenai perusahaan.

b. Akuntabilitas/ accountability, yaitu kejelasan fungsi, struktur, sistem dan pertanggungjawaban perusahaan sehingga pengelolaan perusahaan terlaksana secara efektif.

c. Pertanggungjawaban/ responsibility, yaitu kesesuaian (kepatuhan) di dalam pengelolaan perusahaan terhadap prinsip korporasi yang sehat serta peraturan perundang-undangan yang berlaku.

d. Kemandirian/ independency, yaitu suatu keadaan dimana perusahaan dikelola secara profesional tanpa benturan kepentingan dan pengaruh/ tekanan dari pihak manajemen yang tidak sesuai dengan peraturan dan perundangan yang berlaku dan prinsip-prinsip korporasi yang sehat.

e. Kewajaran/ fairness, yaitu perlakuan yang adil dan setara di dalam memenuhi hak-hak stakeholder yang timbul berdasarkan perjanjian serta peraturan perundang-undangan yang berlaku.

\section{Rencana Strategis (Renstra)}

Ward \& Peppard (2007) mendefinisikan perencanaan merupakan sebuah analisis yang menyeluruh dan sistematis dalam mengembangkan sebuah rencana kegiatan. Chuck Williams (2011) mendefinisikan perencanaan adalah memilih suatu tujuan dan mengembangkan suatu metode atau strategi untuk mencapai tujuan. Jadi perencanaan adalah langkah strategi yang menyeluruh dan sistematis untuk mencapai tujuan. Perencanaan berisikan segala sesuatu yang dibutuhkan untuk mencapai tujuan dan cara terbaik untuk meningkatkan kinerja individu dan organisasi.

Husein Umar (2008) mengutip pengertian strategis para ahli dalam bukunya Strategisc Management in Action, salah satunya seperti dikutip dibawah ini strategis yang diterjemahkan sebagai berikut :

Strategis merupakan tindakan yang bersifat incremental (senantiasa meningkat) dan terus menerus, serta berdasarkan sudut pandang tentang apa yang diharapkan oleh pelanggan di masa depan. Dengan demikian, strategis hampir selalu dimulai dari apa yang dapat terjadi dan bukan dari apa yang terjadi. Terjadinya kecepatan inovasi pasar yang baru dan perubahan pola konsumen memerlukan kompetensi inti (core competencies). Perusahaan perlu mencari kompetensi inti dalam bisnis yang dilakukan. (Hamel dan Prahalad, 1995 dalam Umar, 2008).

Menurut Wheelen dan Hunger (2006), strategis dari sebuah perusahaan merupakan perencanaan utama yang menyeluruh yang merumuskan bagaimana perusahaan akan mencapai misi dan tujuannya. Strategis yang tepat akan mampu memaksimalkan keunggulan bersaing bagi perusahaan.

Berdasarkan penjelasan di atas dapat dikatakan bahwa perencanaan strategis merupakan suatu rencana menyeluruh yang memadukan kekuatan yang dimiliki perusahaan dengan mengevaluasi lingkungan luar dan dalam organisasi untuk menyusun suatu strategis yang sesuai guna mencapai tujuan perusahaan.

\section{Kinerja Unit Internal Audit \& Control}

Pengukuran kinerja (performance measurement) adalah suatu proses penilaian kemajuan pekerjaan terhadap tujuan dan sasaran yang telah ditentukan sebelumnya, termasuk informasi atas: efisiensi penggunaan sumber daya dalam menghasilkan barang dan jasa; kualitas barang dan jasa (seberapa baik barang dan 
jasa diserahkan kepada pelanggan dan sampai seberapa jauh pelanggan terpuaskan); hasil kegiatan dibandingkan dengan maksud yang diinginkan; dan efektivitas tindakan dalam mencapai tujuan (Robertson, 2002). Pengukuran kinerja merupakan suatu alat manajemen yang digunakan untuk meningkatkan kualitas pengambilan keputusan dan akuntabilitas (Whittaker, 2003). Simons (dalam BPKP, 2000) menyebutkan bahwa pengukuran kinerja membantu manajer dalam memonitor implementasi strategis bisnis dengan cara membandingkan antara hasil aktual dengan sasaran dan tujuan strategis.

Menurut Standar kinerja dalam hal pengelolaan fungsi audit internal, penanggungjawab fungsi audit internal harus mengelola fungsi audit internal secara efektif dan efisien untuk memastikan bahwa kegiatan fungsi tersebut memberikan nilai tambah bagi organisasi.

Untuk menetapkan ukuran kinerja yang efektif, Kepala Eksekutif Audit Internal harus terlebih dahulu mengidentifikasi aspek-aspek dalam kinerja audit internal yang kritikal. Salah satu cara yang sering digunakan di antaranya adalah kerangka yang diadaptasi dari pemikiran Kaplan dan Norton (1996), Balanced Scorecard, yang menyarankan aspek pengukuran kinerja audit internal ke dalam perspektif :

a. Inovasi dan pembelajaran, untuk menjawab pertanyaan apakah audit internal mampu berkelanjutan dan menciptakan value bagi perusahaan.

b. Proses Audit Internal, untuk menjawab pertanyaan pada bidang apa audit internal memiliki keahlian.

c. Manajemen/ Auditee, adaptasi perspektif pelanggan, yaitu untuk menjawab pertanyaan bagaimana customer memandang audit internal.

d. Board/ Komite Audit, adaptasi dari perspektif keuangan, untuk menjawab pertanyaan bagaimana audit internal memandang stakeholder.

Jadi pengukuran kinerja adalah suatu metode atau alat yang digunakan untuk mencatat dan menilai pencapaian pelaksanaan kegiatan berdasarkan tujuan, sasaran, dan strategis sehingga dapat diketahui kemajuan unit atau organisasi serta meningkatkan kualitas pengambilan keputusan dalam pengelolaan organisasi yang baik sehingga visi dan misi yang telah ditetapkan dapat tercapai secara optimal.

\section{E. Metodologi}

\section{Tempat Dan Waktu Penelitian}

Penelitian dilakukan di GMF AERO ASIA di Management Building lantai 2 Soekarno-Hatta International airport, Cengkareng-Indonesia. Waktu penelitian dimulai dari surat pengantar dari Universitas Pamulang nomor 225/A/MM/UNPAM/VI/2012 tanggal 21 Juni 2012 sampai dengan Februari 2013.

\section{Lembaga Yang Diteliti}

PT GARUDA MAINTENANCE FACILITIES(GMF) AERO ASIA adalah salah satu perusahaan perseroan terbatas yang mempunyai badan hukum dimana izin pendiriannya dilaksanakan atas dasar surat keputusan Menteri Negara BUMN RI NoS-26 t1/M-BUMN/2002 pada tanggal 8 Maret 2002, yang kemudian di tindaklanjuti dengan pendiri anak perusahaan dengan akte pendirian PT GMFAA No.93 tanggal 26 April 2002 yaitu dikeluarkan oleh kantor notaris Arry Aupratno,SH. Pada tanggal 19 Agustus 2002, GARUDA MAINTENANCE FACILITY yang selama ini menjadi unit bisnis strategis, dari PT GARUDA INDONESIA resmi dipisah (spin off) menjadi PT GARUDA MAINTENANCE FAILITY AERO ASIA. 


\section{Metode Penelitian}

Jenis penelitian kuantitatif kali ini adalah studi korelasional. Studi ini memperlajari hubungan dua variabel atau lebih, yakni sejauh mana variasi dalam satu variabel berhubungan dengan variasi dalam variabel lain

\section{Instrumen Penelitian}

Instrumen penelitian adalah jiwa dari penelitian itu sendiri, sedangkan data merupakan bahan penting yang dianalisis untuk menjawab permasalahan. Mutu instrumen penelitian akan menentukan mutu dari data yang dikumpulkan sehingga tepatlah dikatakan bahwa hubungan instrumen dengan data adalah seperti jantung dan darah, dimana saling terkait antara latar belakang; permasalahan; identifikasi; tujuan; manfaat; kerangka pemikiran; hipotesis penelitian.

Kisi-kisi penyusunan instrumen penelitian terdiri dari 20 pertanyaan yang mewakili variabel-variabel yang diteliti. Dari uraian definisi operasional setiap variabel di atas maka dapat disusun instrumen penelitian ini adalah sebagai berikut :

Tabel 1 Kisi-kisi Penyusunan Instrumen Penelitian

\begin{tabular}{|c|c|c|c|}
\hline \multicolumn{4}{|c|}{ Variabel $X_{1}=$ Good Corporate Governance } \\
\hline No. & Sub Variabel & Indikator & Deskriptor \\
\hline 1 & \multirow{5}{*}{$\begin{array}{l}\text { Pengungkapan \& } \\
\text { Transparansi }\end{array}$} & \multirow{5}{*}{$\begin{array}{l}\text { Keterbukaan (Bab VII } \\
\text { Kebijakan GCG PT. } \\
\text { GMF Aero Asia) }\end{array}$} & $\begin{array}{l}\text { informasi mengenai tujuan, sasaran usaha, } \\
\text { strategis perusahaan. }\end{array}$ \\
\hline 2 & & & $\begin{array}{l}\text { informasi mengenai penilaian terhadap } \\
\text { perusahaan oleh eskternal audiotr, lembaga } \\
\text { pemeringkat kredit, dan lembaga pemeringkat } \\
\text { lainnya. }\end{array}$ \\
\hline 3 & & & $\begin{array}{l}\text { informasi mengenai faktor risiko material yang } \\
\text { dapat diantisipasi, termasuk penilaian } \\
\text { manajemen atas iklim berusaha dan faktor } \\
\text { risiko. }\end{array}$ \\
\hline 4 & & & $\begin{array}{l}\text { informasi penilaian manajemen atas iklim } \\
\text { berusaha dan faktor risiko. }\end{array}$ \\
\hline 5 & & & $\begin{array}{l}\text { informasi mengenai pelaksanaan pedoman } \\
\text { Good Corporate Governance. }\end{array}$ \\
\hline 6 & Kemandirian & $\begin{array}{l}\text { Etika berusaha dan } \\
\text { anti korupsi (Bab X } \\
\text { Kebijakan GCG PT. } \\
\text { GMF Aero Asia) } \\
\end{array}$ & $\begin{array}{l}\text { menjunjung tinggi persaingan yang fair, nilai } \\
\text { sportifitas, dan profesionalisme serta prinsip- } \\
\text { prinsip good corporate governance. }\end{array}$ \\
\hline 7 & \multirow{4}{*}{ Akuntabilitas } & \multirow{4}{*}{$\begin{array}{l}\text { Pengawasan Internal } \\
\text { (Bab III.7 Kebijakan } \\
\text { GCG PT. GMF Aero } \\
\text { Asia) }\end{array}$} & sistem pengawasan internal yang efektif \\
\hline 8 & & & memastikan kebenaran informasi keuangan. \\
\hline 9 & & & $\begin{array}{l}\text { memastikan efektifitas dan efisiensi proses } \\
\text { pengelolaan perusahaan. }\end{array}$ \\
\hline 10 & & & $\begin{array}{l}\text { memastikan kepatuhan pada peraturan } \\
\text { perundang-undangan yang terkait. }\end{array}$ \\
\hline 11 & \multirow[b]{2}{*}{ Petanggungjawaban } & \multirow{2}{*}{$\begin{array}{l}\text { Sistem Audit (Bab IV } \\
\text { Kebijakan GCG PT. } \\
\text { GMF Aero Asia) }\end{array}$} & struktur pengawasan internal yang memadai. \\
\hline 12 & & & $\begin{array}{l}\text { meningkatkan kualitas keterbukaan dan } \\
\text { pelaporan keuangan. }\end{array}$ \\
\hline
\end{tabular}

Jurnal Sekuritas, Vol.1, No.3, Maret 2018 


\begin{tabular}{|c|c|c|c|}
\hline 13 & & & peraturan internal yang bersifat mengikat \\
\hline 14 & \multirow{5}{*}{ Kewajaran } & \multirow{5}{*}{$\begin{array}{l}\text { Pihak-pihak yang } \\
\text { berkepentingan } \\
\text { (Stakeholder) (Bab VI } \\
\text { Kebijakan GCG PT. } \\
\text { GMF Aero Asia) }\end{array}$} & $\begin{array}{lll}\begin{array}{l}\text { menghormati hak } \\
\text { berkepentingan }\end{array} & \text { pihak-pihak yang } \\
\end{array}$ \\
\hline 15 & & & $\begin{array}{l}\text { suatu cara yang memadai untuk memulihkan } \\
\text { hak pihak-pihak yang berkepentingan }\end{array}$ \\
\hline 16 & & & $\begin{array}{l}\text { kesempatan untuk memantau pemenuhan } \\
\text { peraturan perundang-undangan yang berlaku }\end{array}$ \\
\hline 17 & & & $\begin{array}{l}\text { menyampaikan masukan mengenai pemenuhan } \\
\text { peraturan perundang-undangan }\end{array}$ \\
\hline 18 & & & $\begin{array}{l}\text { informasi terkait yang diperlukan untuk } \\
\text { melindungi hak pihak-pihak berkepentingan }\end{array}$ \\
\hline \multicolumn{4}{|c|}{ Variabel $\mathbf{X}_{\mathbf{2}}=$ Rencana Strategis (Biz Plan Guidance - Internal Audit) } \\
\hline No. & Sub Variabel & Indikator & Deskriptor \\
\hline 1 & \multirow{5}{*}{$\begin{array}{l}\text { Mapping tahun } \\
2011\end{array}$} & \multirow{5}{*}{$\begin{array}{l}\text { Program-program } \\
\text { rencana strategis } \\
\text { Unit Internal Audit \& } \\
\text { Control dalam tahun } \\
2011\end{array}$} & melaksanakan Internal Control Development. \\
\hline 2 & & & melaksanakan Audit Plan Execute. \\
\hline 3 & & & melaksanakan Campaign ERM. \\
\hline 4 & & & $\begin{array}{l}\text { melaksanakan People Development } \quad \text { (50\% } \\
\text { certified). }\end{array}$ \\
\hline 5 & & & melaksanakan Review BSC. \\
\hline 6 & \multirow{7}{*}{ Change 2012} & \multirow{7}{*}{$\begin{array}{l}\text { Program-program } \\
\text { rencana strategis } \\
\text { Unit Internal Audit \& } \\
\text { Control dalam tahun } \\
2012\end{array}$} & memiliki New IA BSC. \\
\hline 7 & & & melaksanakan Develop IC. \\
\hline 8 & & & $\begin{array}{l}\text { melaksanakan Comprehensive } \\
\text { balance scorecard. }\end{array}$ \\
\hline 9 & & & memiliki Implemented ERM Framework. \\
\hline 10 & & & melaksanakan Reduce FCAR Open. \\
\hline 11 & & & melaksanakan Set up WBS Policy. \\
\hline 12 & & & $\begin{array}{l}\text { melaksanakan People Development }(75 \%+3 \text { Int'I } \\
\text { certificate). }\end{array}$ \\
\hline
\end{tabular}

Variabel Y = Kinerja Unit Internal Audit \& Control (TI)

\begin{tabular}{|c|c|c|c|}
\hline No. & Sub Variabel & Indikator & Deskriptor \\
\hline 1 & \multirow{5}{*}{$\begin{array}{l}\text { Bord and Audit } \\
\text { Comittee }\end{array}$} & $\begin{array}{l}\text { Penerapan } \\
\text { Transparansi }\end{array}$ & mempermudah pelaksanaan penugasan. \\
\hline 2 & & $\begin{array}{l}\text { Penerapan } \\
\text { Kemandirian }\end{array}$ & menjamin indepensi. \\
\hline 3 & & $\begin{array}{c}\text { Penerapan } \\
\text { Akuntabilitas }\end{array}$ & kian dirasakan manfaatnya. \\
\hline 4 & & $\begin{array}{c}\text { Penerapan } \\
\text { Pertanggungjawaban }\end{array}$ & $\begin{array}{l}\text { mendorong terbentuknya struktur pengawasan } \\
\text { internal yang memadai. }\end{array}$ \\
\hline 5 & & $\begin{array}{l}\text { Penerapan } \\
\text { Kewajaran }\end{array}$ & $\begin{array}{l}\text { meningkatkan proses bisnis dan kontrol serta } \\
\text { pelaksanaan penerapan prinsip-prinsip good } \\
\text { corporate governance. }\end{array}$ \\
\hline 6 & \multirow[t]{2}{*}{$\begin{array}{l}\text { Bord and Audit } \\
\text { Comittee }\end{array}$} & \multirow{2}{*}{$\begin{array}{l}\text { Kedudukan Unit } \\
\text { Internal Audit \& } \\
\text { Control }\end{array}$} & $\begin{array}{l}\text { Pertemuan berkala antara pimpinan Unit } \\
\text { Internal Audit \& Control dengan Komite Audit. }\end{array}$ \\
\hline 7 & & & Komite audit puas atas peran Unit Internal Audit \\
\hline
\end{tabular}

Jurnal Sekuritas, Vol.1, No.3, Maret 2018 


\begin{tabular}{|c|c|c|c|}
\hline & & \multirow[b]{2}{*}{ \& Control dalam perusahaan. } \\
\hline & & & \\
\hline 8 & \multirow{5}{*}{$\begin{array}{l}\text { Internal Audit } \\
\text { Process }\end{array}$} & \multirow{3}{*}{$\begin{array}{l}\text { Pemastian kualitas } \\
\text { audit berkembang }\end{array}$} & $\begin{array}{l}\text { Internal Control Development, Audit plan } \\
\text { execute, review BSC sangat diperlukan. }\end{array}$ \\
\hline 9 & & & $\begin{array}{l}\text { Campaign ERM sangat membantu pelaksanaan } \\
\text { ERM framework. }\end{array}$ \\
\hline 10 & & & $\begin{array}{l}\text { strategis perubahan yang optimal untuk Unit } \\
\text { Internal Audit \& Control di tahun } 2012 \text {. }\end{array}$ \\
\hline 11 & & \multirow{2}{*}{$\begin{array}{l}\text { Persentase realisasi } \\
\text { dengan rencana }\end{array}$} & $\begin{array}{l}\text { Unit Internal Audit \& Control sudah } \\
\text { melaksanakan aktivitas audit sesuai dengan } \\
\text { perencanaan audit. }\end{array}$ \\
\hline 12 & & & $\begin{array}{l}\text { Lap Audit penugasan Unit Internal Audit \& } \\
\text { Control memenuhi prosedur audit. }\end{array}$ \\
\hline 13 & \multirow{3}{*}{$\begin{array}{l}\text { Innovation and } \\
\text { Capabilities }\end{array}$} & $\begin{array}{l}\text { Persentasi staf yang } \\
\text { bersertifikat }\end{array}$ & pembelajaran dan inovasi. \\
\hline 14 & & \multirow{2}{*}{$\begin{array}{c}\text { Due professional } \\
\text { care dengan kualitas } \\
\text { audit }\end{array}$} & rencana strategis TI sangat berkesinambungan. \\
\hline 15 & & & $\begin{array}{l}\text { Pengembangan SDM sesuai dengan kompetensi } \\
\text { profesionalismenya. }\end{array}$ \\
\hline 16 & \multirow{5}{*}{$\begin{array}{l}\text { Business Unit } \\
\text { Management }\end{array}$} & \multirow{5}{*}{$\begin{array}{l}\text { Manajemen puas } \\
\text { dengan hasil audit }\end{array}$} & $\begin{array}{l}\text { memberikan solusi yang tepat bagi } \\
\text { permasalahan yang dihadapi manajemen. }\end{array}$ \\
\hline 17 & & & $\begin{array}{l}\text { sesuai dengan IPPF (The International } \\
\text { Professional Practise Framework) of Internal } \\
\text { Auditing }\end{array}$ \\
\hline 18 & & & $\begin{array}{l}\text { hasil penugasan audit semakin berkualitas } \\
\text { sehingga membantu proses bisnis. }\end{array}$ \\
\hline 19 & & & $\begin{array}{l}\text { hasil penugasan audit semakin berkualitas } \\
\text { sehingga permintaan jasa audit bertambah. }\end{array}$ \\
\hline 20 & & & $\begin{array}{l}\text { hasil penugasan audit semakin berkualitas } \\
\text { sehingga rekomendasi audit dijalankan. }\end{array}$ \\
\hline
\end{tabular}

\section{Sumber Dan Cara Pengumpulan Data}

\section{a. Sumber Data}

Data primer umumnya berupa : karakteristik demografi atau sosioekonomi, sikap atau pendapat, kesadaran atau pengetahuan, minat, motivasi, perilaku (tindakan dan penggunaan). Data primer dalam penelitian ini adalah data nilai jawaban dari kuisioner mengenai variable-variabel yang diteliti.

Adapun data sekunder terdiri dari data sekunder internal suatu organisasi (terutama untuk penelitian terapan dan studi kasus); data sekunder eksternal yang dipublikasikan mencakup catatan-catatan, hasil-hasil studi, hasil-hasil publikasi, peraturan-peraturan serta dokumen kebijakan dari lembaga yang terkait

\section{b. Cara pengumpulan Data}

\section{1) Survei Lokasi}

Survey lokasi dilakukan untuk memperoleh data-data primer dan sekunder baik data-data numerik maupun data-data (dokumen) kebijakan dan peraturanperaturan yang terkait dengan proses pelaksanaan Good Corporate Governance ke 
stakeholder dan pelaksanaan rencana strategis Unit Internal Audit \& Control GMF Aero Asia

\section{2) Kuisioner}

Kegiatan penelitian dilakukan secara langsung pada obyek penelitian untuk mendapatkan data aktual secara tertulis yang akan menjadi pokok bahasan penulisan. Penulis menyerahkan kuisioner kepada responden melalui persetujuan pimpinan dari organisasi ini. Hasil kuisioner dikumpulkan, diolah dan dianalisis sebagai dasar penelitian ini.

\section{3) Studi Kepustakaan}

Kegiatan penelitian dilakukan dengan mengumpulkan data dari berbagai literature, seperti skripsi atau tesis, buku, jurnal, surat kabar dan literature lainnya yang berkaitan dengan masalah yang diteliti.

\section{c. Teknis Analisis Data \\ 1) Rancangan Analisis}

Untuk menguji good corporate governance, rencana strategis dan kinerja digunakan model persamaan regresi sederhana (simple linear regression).

\section{2) Uji Validitas}

Validitas adalah alat untuk mengukur sah atau valid tidaknya suatu suatu kuisioner. Suatu kuisioner dikatakan valid jika pertanyaan pada kuisioner mampu untuk mengungkapkan sesuatu yang diukur oleh kuisioner.

\section{3) Uji Realibilitas}

Realibilitas adalah alat untuk mengukur suatu kuisioner yang merupakan indikator dari variabel atau konstrak. Suatu kuisioner dikatakan reliabel atau handal jika jawaban responden terhadap pernyataan adalah konsisten atau stabil dari waktu ke waktu.

\section{4) Uji Homogenitas}

Uji kesamaan dua varians digunakan untuk menguji apakah kedua data tersebut homogen, yaitu dengan membandingkan kedua variansnya. Jika kedua variansnya sama besar, maka uji homogenitas ini tidak perlu dilakukan lagi karena datanya sudah dapat dianggap homogen. Namun untuk varians yang tidak sama besarnya, perlu diadakan pengujian homogenitas melalui uji kesamaan dua varians ini.

\section{5) Uji Normalitas}

Uji Normalitas bertujuan untuk menguji apakah dalam model regresi, variabel pengganggu atau residual memiliki distribusi normal. Seperti diketahui bahwa uji $t$ dan $F$ mengasumsikan bahwa nilai residual mengikuti distribusi normal. Model regresi yang baik adalah yang memiliki distribusi normal atau mendekati normal.

\section{d. Uji Hipotesis}

\section{1) Uji Parsial (Uji T)}

Uji $t$ digunakan untuk mengetahui pengaruh masing-masing variabel independen terhadap variabel dependen. Kriteria pengujian yang digunakan adalah jika $p$ value $<0,05$, maka Ha diterima dan Jika $p$ value $>0,05$, maka Ha ditolak.

\section{2) Uji Simultan (Uji F)}

Uji F digunakan untuk mengetahui ada tidaknya pengaruh simultan variabelvariabel independen terhadap variabel dependen. Kriteria pengujian yang digunakan adalah jika probability value ( $p$ value) $<0,05$, maka Ha diterima dan jika $p$ value $>$ 0,05, maka Ha ditolak. 


\section{3) Uji Regresi Linier}

Dalam penelitian ini digunakan metode model persamaan regresi sederhana (simple linear regression) dan moderated regression analysis (MRA). Simple linear regssion digunakan untuk menguji hubungan antara partisipasi dengan kepuasan pemakai, sementara moderated regression analysis digunakan untuk menguji pengaruh interaksi faktor kontijensi.

\section{F. Hasil dan Pembahasan}

\section{Deskriptif Data}

Banyaknya responden adalah 49 , dilihat dari jenis kelamin 30 responden atau $61,2 \%$ berjenis kelamin laki-laki. Sedangkan 19 responden atau 38,8 \% responden berjenis kelamin perempuan.

Dilihat dari usia, 9 responden atau $18,4 \%$ berusia $<25$ tahun, 18 responden atau $36,7 \%$ berusia 26 - 35 tahun, 18 responden atau $36,7 \%$ responden berusia 36 - 45 tahun, sedangkan 4 responden atau 8,2\% responden berusia > 46 tahun.

Dilihat dari masa kerja, 25 responden atau $51,0 \%$ responden bekerja selama $<5$ tahun, 5 responden atau 10,2\% bekerja selama $6-10$ tahun, 3 responden atau $6,1 \%$ bekerja selama $11-15$ tahun, 12 responden atau $24,5 \%$ bekerja selama $16-20$ tahun sedangkan 4 responden atau 8,2 \% telah bekerja $>21$ tahun.

Dilihat dari tingkat pendidikan, 4 responden atau 8,2 \% responden berpendidikan SMA, 28 responden atau 57,1\% berpendidikan S1, 17 responden atau $34,7 \%$ penelitian ini berpendidikan S2.

Dilihat dari jabatan, 36 responden atau 73,5\% jabatannya adalah staff, 7 responden atau 14,3\% jabatannya adalah Senior staff, 5 responden atau 10,2\% jabatannya adalah General Manager (GM), 1 responden atau 2,0\% jabatannya adalah Vice President (VP).

\section{Analisis Data Uji Persyaratan Instrumen Penelitian}

\section{a. Uji Validitas}

Pengujian Validitas yang digunakan oleh penulis adalah pengujian statistic korelasi moment tangkar (correlation statistics product moment) dari Pearson.

Hasil analisis SPSS for windows version 20.0 untuk uji validitas pada instrumen data kuisioner dapat dijelaskan sebagai berikut :

1) Variabel Good Corporate Governance sebagai variabel $X_{1}$ menunjukan bahwa butir pertanyaan (instrumen 1 - 18) untuk kuisioner variabel Good Corporate Governance terhadap Kinerja Unit Internal Audit \& Control memiliki nilai koefisien korelasi positif dan > 0,05 maka instrumen 1 sampai dengan 18 valid. Dengan demikian, semua instrumen tersebut dinyatakan valid untuk digunakan sebagai alat ukur dalam penenlitian ini.

2) Variabel rencana strategis terhadap kinerja Unit Internal Audit \& Control, sebagai variabel $\mathrm{X}_{2}$ menunjukan bahwa semua butir pertanyaan (Instrumen 112) untuk kuisioner variabel rencana strategis terhadap kinerja Unit Internal Audit \& Control memiliki nilai koefisien korelasi positif dan > 0,05 maka instrumen 1 sampai dengan 12 valid. Dengan demikian, semua instrumen tersebut dinyatakan valid untuk digunakan sebagai alat ukur dalam penenlitian ini.

3) Variabel kinerja Unit Internal Audit \& Control, sebagai variabel Y menunjukan bahwa butir pertanyaan (instrumen $1-20$ ) untuk kuisioner Variabel kinerja Unit Internal Audit \& Control memiliki nilai koefisien korelasi positif dan > 0,05 maka 
instrumen 1 sampai dengan 20 valid. Dengan demikian, semua instrumen tersebut dinyatakan valid untuk digunakan sebagai alat ukur dalam penenlitian ini.

\section{b. Uji Realibilitas}

Hasil analisis SPSS for Windows Version Release 20.0 untuk uji reliabilitas terhadap data kuisioner dapat dilihat dibawah ini :

1) Good Corporate Governance

Hasil analisis menunjukan bahwa koefisien alpha hitung untuk variabel Good Corporate Governance terhadap Kinerja Unit Internal Audit \& Control > 0,60 (0,933 $>0,60$ ), sehingga dapat disimpulkan bahwa kuisioner atau alat pengukur data tersebut untuk variabel Good Corporate Governance terhadap Kinerja Unit Internal Audit \& Control bersifat reliable atau dapat dipercaya.

2) Rencana Strategis

Hasil analisis menunjukan bahwa koefisien alpha hitung untuk variabel rencana strategis terhadap kinerja Unit Internal Audit \& Control > 0,60 (0,909 > 0,60 ), sehingga dapat disimpulkan bahwa kuisioner atau alat pengukur data tersebut untuk independensi terhadap kualitas audit bersifat reliable atau dapat dipercaya.

3) Kinerja Unit Internal Audit \& Control

Hasil analisis menunjukan bahwa koefisien alpha hitung untuk variabel Kinerja Unit Internal Audit \& Control > 0,60 (0,940 > 0,60), sehingga dapat disimpulkan bahwa kuisioner atau alat pengukur data tersebut untuk motivasi terhadap Kinerja Unit Internal Audit \& Control bersifat reliable atau dapat dipercaya.

\section{c. Analisis Data Uji Persyaratan Uji Hipotesis}

1) Uji Normalitas

Pengujian asumsi normalitas data diperlukan untuk memutuskan apakah hipotesis akan diuji dengan statistik parametrik atau statistik non parametrik.

Jika hasil pengujian asumsi ini menunjukan data berdistribusi normal maka hipotesis akan diuji dengan statistik parametrik. Sebaliknya jika hasil dari pengujian asumsi ini menunjukan data tidak berdistribusi normal, maka alat uji hipotesis digunakan statistik non parametrik. Hasil uji normalitas dapat dilihat di gambar 2 dan 3 dibawah ini :

\section{Gambar 2 Gambar Histogram Normalitas Data Variabel Kinerja Unit Internal Audit \& Control}

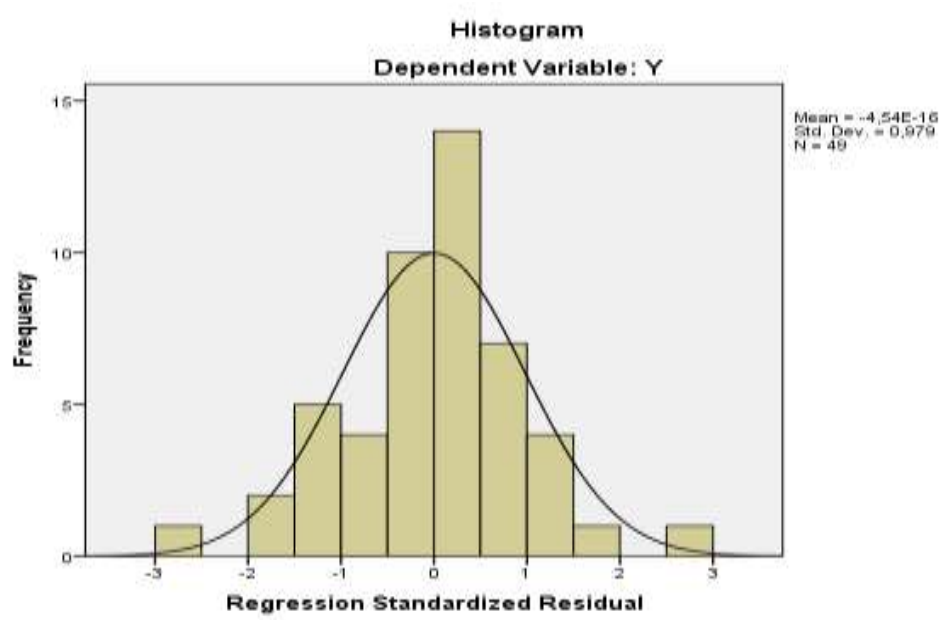

Jurnal Sekuritas, Vol.1, No.3, Maret 2018 


\section{Gambar 3 Gambar P-P plot Normalitas Data Variabel Kinerja Unit Internal Audit \& Control}

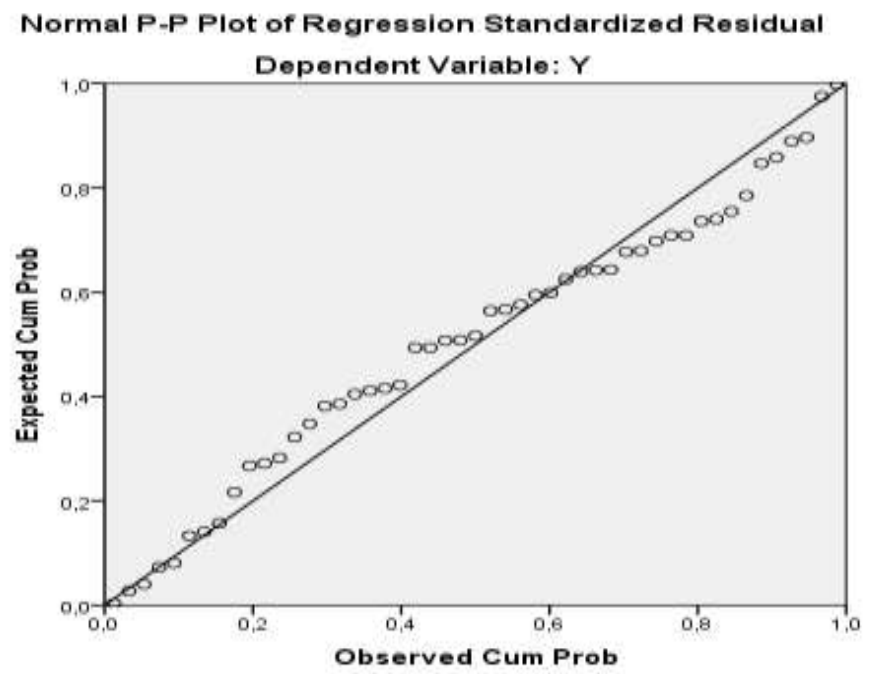

Dengan melihat tampilan grafik histogram maupun grafik normal P-Plot di atas dapat disimpulkan bahwa grafik histogram memberikan pola distribusi yang mendekati normal. Sedangkan pada grafik normal P-Plot terlihat titik-titik menyebar disekitar garis diagonal, serta arah penyebarannya mengikuti arah garis diagonal. Kedua grafik tersebut menunjukkan bahwa model regresi layak dipakai karena memenuhi asumsi normalitas.

\section{2) Uji Homogenitas}

Hasil analisis SPSS for Windows Version Release 20.0 untuk uji homogenitas seperti yang tampak pada tabel 2 di bawah ini :

Tabel 2 Tabel Homogenitas Variabel

\begin{tabular}{|ll|r|r|r|r|}
\hline & \multicolumn{1}{|c|}{$\begin{array}{c}\text { Levene } \\
\text { Statistic }\end{array}$} & \multicolumn{1}{c|}{ df1 } & \multicolumn{1}{c|}{ df2 } & \multicolumn{1}{c|}{ Sig. } \\
\hline & $\begin{array}{l}\text { Based on Mean } \\
\text { Based on Median }\end{array}$ & 2,307 & 3 & 45 &, 089 \\
Kinerja Unit &, 482 & 3 & 45 &, 696 \\
$\begin{array}{l}\text { Internal Audit \& } \\
\text { Control }\end{array}$ & $\begin{array}{l}\text { and with adjusted } \\
\text { df } \\
\text { Based on trimmed } \\
\text { mean }\end{array}$ &, 482 & 3 & 15,954 &, 699 \\
& 1,988 & 3 & 45 &, 129 \\
\hline
\end{tabular}

Hasil analisis dari table 2 di atas Based on Mean diperoleh signifikansi 0,089 $>0,05$ sehingga dapat disimpulkan bahwa data penelitian ini adalah homogen.

\section{3) Uji Linieritas}

Uji linier dalam penelitian ini diolah dengan menggunakan program SPSS for window release 20.0 dimana hasil akhirnya memberikan keluaran (output) sebagai berikut :

i. Uji Linieritas antara variabel $Y$ dengan variabel $X_{1}$ 
Hasil analisis menunjukkan bahwa harga $F$ sebesar 1,139 dengan signifikansi 0,374. Interpretasi hasil analisis menunjukkan bahwa sig. $(1,139)>$ a $(0,05)$ berarti uji linieritas antara variabel kinerja Unit Internal Audit \& Control dengan variabel Good Corporate Governance adalah model regresi linier.

ii. Uji Linieritas antara variabel $Y$ dengan variabel $X_{2}$

Hasil analisis menunjukkan bahwa harga $F$ sebesar 1,378 dengan signifikansi 0,215. Interpretasi hasil analisis menunjukkan bahwa sig. $(1,378)>$ a $(0,05)$ berarti uji linieritas antara variabel kinerja Unit Internal Audit \& Control dengan variabel rencana strategis adalah model regresi linier.

\section{4) Uji Multikolinieritas}

Uji multikolinieritas dengan program SPSS for window release 20.0 dilakukan dengan uji regresi, dengan patokan VIF (variance inflation factor) dan koefisien korelasi antar variabel bebas. Kriteria yang digunakan adalah :

i. Jika nilai VIF di sekitar angka 1 atau memiliki tolerance mendekati 1, maka dikatakan tidak terdapat masalah multikolinieritas dalam model regresi;

ii. Jika koefisien korelasi antar variabel bebas kurang dari 0,5 maka terdapat masalah multikolinieritas.

Hasil uji multikolinieritas dalam pembahasan ini seperti tampal pada tabel 3 sebagai berikut :

Tabel 3 Tabel Multikolinieritas Variabel $X_{1}$ dan $X_{2}$ Coefficients $^{\mathrm{a}}$

\begin{tabular}{|c|c|c|c|}
\hline \multicolumn{2}{|c|}{ Model } & \multicolumn{2}{c|}{ Collinearity Statistics } \\
\cline { 3 - 4 } 1 & $\mathrm{X}_{1}$ & Tolerance & VIF \\
\cline { 2 - 4 } & $\mathrm{X}_{2}$ &, 833 & 1,200 \\
\hline
\end{tabular}

a. Dependent Variable: $Y$

Hasil analisis berdasarkan tabel 3 ternyata nilai VIF mendekati angka 1 untuk semua variabel bebasnya, demikian pula dengan nilai tolerance mendekati 1 untuk semua variabel bebasnya. Dapat disimpulkan bahwa dalam regresi antara variabel bebas Good Corporate Governance $\left(\mathrm{X}_{1}\right)$ dengan rencana strategis $\left(\mathrm{X}_{2}\right)$ terhadap kinerja Unit Internal Audit \& Control tidak terjadi multikolinieritas antar variabel bebas.

\section{5) Uji Heterokedastisitas}

Hasil uji Heterokedastisitas dengan program SPSS for window release 20.0 adalah grafik untuk data hubungan antara Good Corporate Governance $\left(\mathrm{X}_{1}\right)$ dengan rencana strategis $\left(\mathrm{X}_{2}\right)$ terhadap kinerja Unit Internal Audit \& Control : 


\section{Gambar 4 Gambar Grafik Heterokedastisitas}

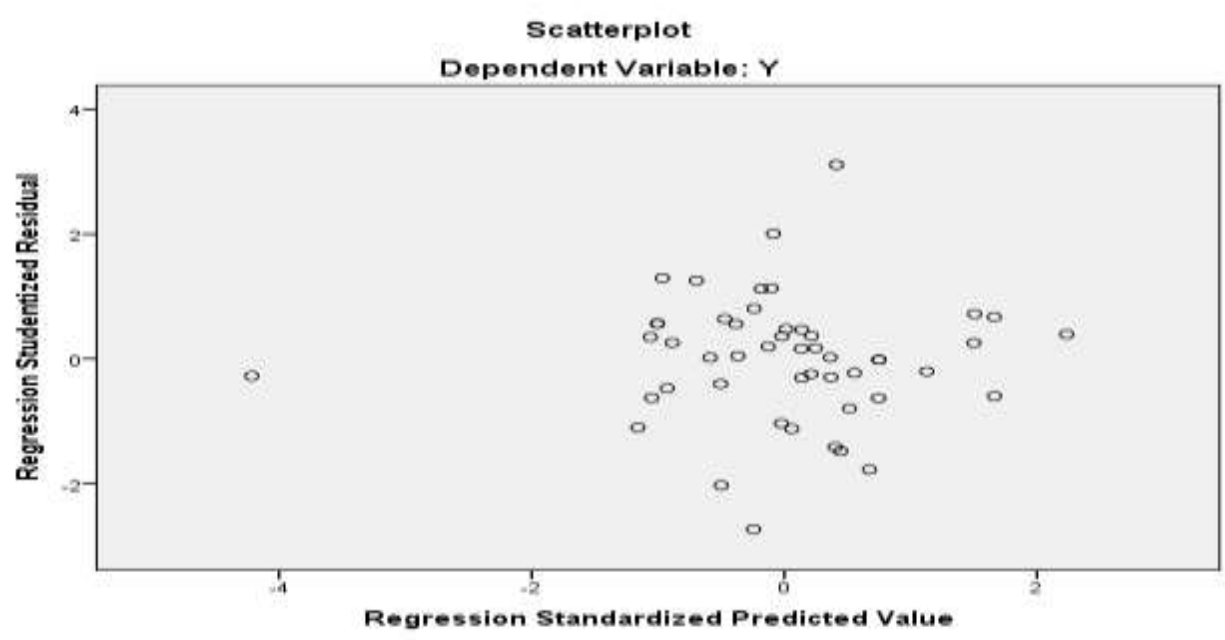

Pada grafik di atas tampak titik-titik menyebar di atas dan di bawah sumbu $Y$, tidak terjadi pola tertentu. Dengan demikian dapat disimpulkan bahwa tidak terjadi heterokedastisitas.

\section{6) Uji Autokorelasi}

Hasil uji Autokorelasi dengan program SPSS for window release 20.0 adalah koefisien Durbin-Watson besarnya 2,214 mendekati 2. Dengan demikian dapat disimpulkan bahwa regresi antara variabel Good Corporate Governance $\left(\mathrm{X}_{1}\right)$ dan rencana strategis $\left(\mathrm{X}_{2}\right)$ terhadap kinerja Unit Internal Audit \& Control $(\mathrm{Y})$ tidak terjadi autokorelasi.

\section{d. Analisis Data Uji Hipotesis}

1) Hasil Uji Regresi

Uji regresi linier dalam penelitian ini diolah dengan menggunakan program SPSS for window release 20.0 dimana hasil akhirnya memberikan keluaran (output) berupa tabel descriptive statistics, tabel correlationsdan tabel coefficients. Secara rinci diuraikan berikut ini :

i. Tabel Deskriptive Statistics

Berisi nilai rata-rata variabel terikat $\mathrm{Y}$ dan Variabel bebas $\mathrm{X} 1$, dan $\mathrm{X} 2$ serta standar deviasi dari masing-masing variabel tersebut.

ii. Tabel Matrik Interkorelasi (Corelations)

Matrik ini berisi korelasi lugas antara semua ubahan yang dimasukan dalam model analisis regresi linear berganda, terdapat pula korelasi parsial antara variabel $\mathrm{X}$ dengan variabel terikat $\mathrm{Y}$.

iii. Tabel Model Summary

Tabel ini berisi nilai koefisien kolerasi berganda $(R)$, dan determinasi berganda $\left(R^{2}\right)$, nilai $R$ menunjukan hubungan antara ketiga variabel $X$ dengan variabel $Y . R^{2}$ menunjukkan berapa besar persentase variabel $Y$ diterangkan variabel $X$ secara bersama-sama.

iv. Tabel Anova

Dalam tabel Anova berisi nilai jumlah kuadrat regresi, kuadrat residual dan kuadrat total, nilai rata-rata kuadrat regresi serta nilai $\mathrm{F}$ test.

v. Tabel Coefficients 
Berisi nilai konstanta (bo), nilai koefisien $b_{1}$ dan $b_{2}$, nilai signifikasi uji "t-test" dan persamaan garis regresi, dirumuskan sebagai berikut :

$Y=b o+b_{1} X_{1}+b_{2} X_{2}+\varepsilon$

\section{2) Uji Korelasi Kinerja Unit Internal Audit \& Control}

Untuk membaca tabel kita harus mengetahui kekuatan hubungan yang telah menjadi standar koefisien korelasi. Menurut Alhusin (2002:157) menyatakan kekuatan hubungan antara variabel dan koefisien sebagai berikut :

$$
\begin{array}{ll}
<0,20: \text { Tidak ada korelasi } \\
0,20-0,40 & : \text { Korelasi rendah } \\
0,40-0,70 & : \text { Korelasi sedang } \\
0,70-0,90 & : \text { Korelasi tinggi } \\
0,90-1,00 & : \text { Korelasi sangat tinggi } \\
=1,00 & : \text { Korelasi sempurna }
\end{array}
$$

\begin{tabular}{|c|c|c|c|c|}
\hline & & $\mathrm{Y}$ & $\mathrm{X}_{1}$ & $\mathrm{X}_{2}$ \\
\hline \multirow{3}{*}{$\begin{array}{l}\text { Pearson } \\
\text { Correlation }\end{array}$} & $Y$ & $\begin{array}{l}1,00 \\
0\end{array}$ & ,556 & ,744 \\
\hline & $\mathrm{X}_{1}$ & ,556 & 1,000 & ,409 \\
\hline & $\mathrm{X}_{2}$ & 744 & 409 & 1,000 \\
\hline \multirow{3}{*}{ Sig. (1-tailed) } & $\mathrm{Y}$ & & 000 &, 000 \\
\hline & $\mathrm{X}_{1}$ &, 000 & &, 002 \\
\hline & $X_{2}$ &, 000 & ,002 & \\
\hline \multirow{3}{*}{$\mathrm{N}$} & $\mathrm{Y}$ & 49 & 49 & 49 \\
\hline & $\mathrm{X}_{1}$ & 49 & 49 & 49 \\
\hline & $\mathrm{X}_{2}$ & 49 & 49 & 49 \\
\hline
\end{tabular}

\section{Tabel 4 Tabel Koefisien Korelasi Kinerja Unit Internal Audit \& Control} Correlations

Berdasarkan tabel 4 di bawah ini dapat disimpulkan, bahwa pengaruh antara Variabel Good Corporate Governance $\left(\mathrm{X}_{1}\right)$ dengan kinerja Unit Internal Audit \& Control $(\mathrm{Y})$ adalah sedang atau mempunyai berpengaruh yang sedang ( $\mathrm{rx} 1 \mathrm{y}=0,556)$ dan mempunyai arah hubungan yang positif. Arah hubungan positif maksudnya adalah apabila variabel Good Corporate Governance $\left(X_{1}\right)$ naik $1 \%$ maka akan menaikkan kinerja Unit Internal Audit \& Control $(Y)$ sebesar 55,6\%. Sebaliknya bila variabel Good Corporate Governance $\left(X_{1}\right)$ turun $1 \%$ akan menurunkan kinerja Unit Internal Audit \& Control (Y) sebesar 55,6\%.

Bila nilai $\mathrm{rx}_{1} \mathrm{y}=0,556$ dikuadratkan maka akan didapat hasil $(0,556)^{2}=0,309$ atau 30,9\% kinerja Unit Internal Audit \& Control $(Y)$ dipengaruhi oleh Good Corporate Governance $\left(\mathrm{X}_{1}\right)$ sedangkan sisanya $69,1 \%$ dipengaruhi oleh variabel lain.

Pengaruh Variabel rencana strategis $\left(X_{2}\right)$ dengan kinerja Unit Internal Audit \& Control $(\mathrm{Y})$ adalah tinggi atau mempunyai pengaruh kuat $\left(\mathrm{rx}_{2} \mathrm{y}=0,744\right)$ dan mempunyai arah hubungan yang positif. Arah hubungan positif maksudnya adalah apabila variabel rencana strategis $\left(\mathrm{X}_{2}\right)$ naik $1 \%$ maka akan menaikkan kinerja Unit Internal Audit \& Control (Y) sebesar 74,4\%. Sebaliknya bila variabel rencana strategis $\left(\mathrm{X}_{2}\right)$ turun $1 \%$ akan menurunkan kinerja Unit Internal Audit \& Control (Y) sebesar $74,4 \%$.

Bila nilai rx2y $=0,744$ dikuadratkan maka akan didapat hasil $(0,744)^{2}=0,553$ atau 55,3\% kinerja Unit Internal Audit \& Control (Y) dipengaruhi oleh rencana strategis $\left(X_{2}\right)$ sedangkan sisanya $44,7 \%$ dipengaruhi oleh variabel lain. 
3) Uji Regresi Kinerja Unit Internal Audit \& Control

Tabel 5 Tabel Statistik Deskriptif Kinerja Unit Internal Audit \& Control Descriptive Statistics

\begin{tabular}{|r|r|r|r|}
\hline & Mean & \multicolumn{1}{|c|}{$\begin{array}{c}\text { Std. } \\
\text { Deviation }\end{array}$} & N \\
\hline $\mathrm{Y}$ & 76,82 & 10,582 & 49 \\
\hline $\mathrm{X}_{1}$ & 70,67 & 9,835 & 49 \\
\hline $\mathrm{X}_{2}$ & 43,92 & 6,873 & 49 \\
\hline
\end{tabular}

Berdasarkan tabel 5 di atas menyatakan bahwa Kinerja Unit Internal Audit \& Control mempunyai nilai rata-rata sebesar 76,82 dan standar deviasi sebesar 10,582; nilai rata-rata Good Corporate Governance sebesar 70,67 dan standar deviasi sebesar 9,835; nilai rata-rata rencana strategis sebesar 43,92 dan standar deviasi sebesarnya 6,873.

\section{4) Uji Koefisien Determinasi}

Dari tabel 6 di bawah ini, angka koefisien korelasi berganda ( $R$ ) sebesar 0,794 atau $79,4 \%$. Angka antara kedua variabel bebas tersebut, Good Corporate Governance $\left(X_{1}\right)$, rencana strategis $\left(X_{2}\right)$ secara bersama-sama menunjukan hubungan yang positif dan searah dengan kinerja Unit Internal Audit \& Control ( $Y$ ), hal ini bisa diketahui melalui angka koefisien determinasi $\left(R^{2}\right)$ sebesar $63,0 \%$ artinya pengaruh Good Corporate Governance $\left(X_{1}\right)$ dan rencana strategis $\left(X_{2}\right)$ terhadap kinerja Unit Internal Audit \& Control (Y), mempunyai pengaruh yang sedang sebesar $63,0 \%$, sedangkan sisanya sebesar $27,0 \%$ dipengaruhi oleh variabel lain yang tidak dimasukan kedalam penelitian ini.

Tabel 6 Tabel Koefisien Determinasi Kinerja Unit Internal Audit \& Control Model Summary

\begin{tabular}{|c|c|c|c|c|c|c|c|c|c|}
\hline \multirow[t]{2}{*}{ Model } & \multirow[t]{2}{*}{$\mathrm{R}$} & \multirow{2}{*}{$\begin{array}{l}\mathrm{R} \\
\mathrm{Sq}\end{array}$} & \multirow{2}{*}{\begin{tabular}{|c|} 
Adjust \\
ed R \\
Sq
\end{tabular}} & \multirow{2}{*}{$\begin{array}{c}\text { Std. } \\
\text { Error } \\
\text { of the } \\
\text { Est }\end{array}$} & \multicolumn{5}{|c|}{ Change Statistics } \\
\hline & & & & & $\begin{array}{c}\mathrm{RSQ} \\
\text { Chang } \\
\mathrm{e}\end{array}$ & F Change & df1 & df2 & $\begin{array}{l}\text { Sig. F } \\
\text { Change }\end{array}$ \\
\hline &, 794 &, 63 & ,614 & 6,575 & ,630 & 39,177 & 2 & 46 & 000 \\
\hline
\end{tabular}

a. Predictors: (Constant), X2, X1

b. Dependent Variable: $Y$

\section{Hasil Uji Regresi Linear Sederhana dengan Uji T Hitung}

Hasil perhitungan dan pengolahan dengan menggunakan program SPSS release 20.0 antara lain diperoleh output sebagaimana dijelaskan sebagai berikut :

\section{Good Corporate Governance $\left(\mathrm{X}_{1}\right)$ berpengaruh secara signifikan} terhadap kinerja Unit Internal Audit \& Control (Y)

Besarnya pengaruh antara variabel Good Corporate Governance $\left(X_{1}\right)$ terhadap kinerja Unit Internal Audit \& Control ( $\mathrm{Y}$ ) yang telah dihitung koefisien korelasinya adalah 0,556 atau $\left(\mathrm{rx}_{1} \mathrm{y}=0,556\right)$. Hal ini menunjukan berpengaruh sedang terhadap kinerja Unit Internal Audit \& Control. Sedangkan untuk menyatakan besar kecilnya kontribusi variabel $\left(X_{1}\right)$ terhadap $Y$ atau koefisien diterminan $=r^{2} \times 100 \%$ atau $0,309 \times 100 \%=30,9 \%$ sedangkan sisanya $69,1 \%$ dipengaruhi oleh variabel lain. Kemudian untuk mengetahui tingkat signifikan koefisien korelasi $\left(X_{1}\right)$ terhadap $Y$ 
dengan metode dua sisi (2-tailed) dari output SPPS (diukur dari probabilitas) menghasilkan angka 0,00 seperti tampak pada tabel 4.7 di bawah ini :

Tabel 7 Tabel Regresi Linear Variabel $\mathrm{X}_{1}$ terhadap $\mathrm{Y}$ Coefficients $^{\mathrm{a}}$

\begin{tabular}{|c|l|r|r|r|r|r|}
\hline \multirow{2}{*}{ Model } & \multicolumn{2}{|c|}{$\begin{array}{c}\text { Unstandardized } \\
\text { Coefficients }\end{array}$} & $\begin{array}{c}\text { Standardize } \\
\text { d } \\
\text { Coefficients }\end{array}$ & \multirow{2}{*}{$t$} & \multirow{2}{*}{ Sig. } \\
\cline { 2 - 7 } & \multicolumn{1}{|c|}{ B } & Std. Error & Beta & & \\
\hline \multirow{2}{*}{1} & (Constant) & 34,528 & 9,306 & & 3,710 &, 001 \\
\cline { 2 - 7 } & $\mathrm{X}_{1}$ &, 598 &, 130 &, 556 & 4,587 &, 000 \\
\hline
\end{tabular}

a. Dependent Variable: $Y$

Probabilitas jauh dibawah 0,05, maka pengaruh antara Good Corporate Governance terhadap kinerja Unit Internal Audit \& Control adalah signifikan. Arti signifikan adalah berkemungkinan atau berpeluang betul-betul benar, bukan benar karena secara kebetulan. Jadi pengaruh Good Corporate Governance adalah berkemungkinan atau berpeluang betul-betul benar berpengaruh terhadap kinerja Unit Internal Audit \& Control.

Dari Tabel 7 Coeficients menggambarkan persamaan regresi sederhana sebagai berikut

\begin{tabular}{|ccc|}
\hline $\mathbf{Y}$ & $=$ & $\mathbf{3 4 , 5 2 8}+\mathbf{0 , 5 9 8} \mathbf{X}_{\mathbf{1}}$ \\
\hline Dimana $: \mathrm{X}_{1}=$ Good Corporate Governance \\
$\mathrm{Y}=$ Kinerja Unit Internal Audit \& Control
\end{tabular}

Konstanta sebesar 34,528, hal ini menandakan jika variabel Good Corporate Governance $\left(\mathrm{X}_{1}\right)=0$, maka kinerja Unit Internal Audit \& Control bernilai positif yaitu 34,528. Nilai Koefisien regresi variabel Good Corporate Governance (b) bernilai positif yaitu 0,598 , maka dapat diartikan setiap kenaikan $1 \%$ maka akan meningkatkan kinerja Unit Internal Audit \& Control 0,598.

Nilai t hitung untuk variabel bebas Good Corporate Governance 4,587 lebih besar dari t-tabel 1,679 (4,587 > 1,679) artinya dapat disimpulkan bahwa Good Corporate Governance berpengaruh signifikan terhadap kinerja Unit Internal Audit \& Control. Nilai Koefisien b positif, artinya jika Good Corporate Governane naik maka kinerja Unit Internal Audit \& Control juga naik.

Nilai signifikansi $<0,05$ terlihat pada kolom Sig (Signifikan) pada tabel 4.7 Coeficients Sig. 0,000 atau lebih kecil dari nilai probabilitas $0,05(0,000<0,05)$. Maka dapat disimpulkan bahwa Good Corporate Governane berpengaruh terhadap kinerja Unit Internal Audit \& Control. Nilai Koefisien b positif, artinya jika Good Corporate Governane naik maka kinerja Unit Internal Audit \& Control juga naik.

\section{Rencana strategis $\left(X_{2}\right)$ berpengaruh secara signifikan terhadap kinerja Unit Internal Audit \& Control (Y)}

Besarnya pengaruh antara variabel rencana strategis $\left(\mathrm{X}_{2}\right)$ terhadap kinerja Unit Internal Audit \& Control (Y) yang dihitung koefisien korelasi adalah 0,744 atau $\left(\mathrm{rx}_{2} \mathrm{y}=0,744\right)$. Kemudian untuk mengetahui tingkat signifikan koefisien korelasi $\left(\mathrm{X}_{2}\right)$ terhadap $Y$ dengan metode dua sisi (2-tailed) dari output SPPS (diukur dari probabilitas) menghasilkan angka 0,00 .

Probabilitas jauh dibawah 0,05 maka pengaruh rencana strategis terhadap kinerja Unit Internal Audit \& Control adalah signifikan. Arti signifikan adalah berkemungkinan atau berpeluang betul-betul benar, bukan benar karena secara Jurnal Sekuritas, Vol.1, No.3, Maret 2018 
kebetulan. Jadi pengaruh rencana strategis adalah berkemungkinan atau berpeluang betul-betul benar berpengaruh terhadap kinerja Unit Internal Audit \& Control, seperti yang tapak pada tabel 4.8 di bawah ini :

Tabel 8 Tabel Regresi Linear Variabel $\mathrm{X}_{2}$ terhadap $\mathrm{Y}$ Coefficients $^{a}$

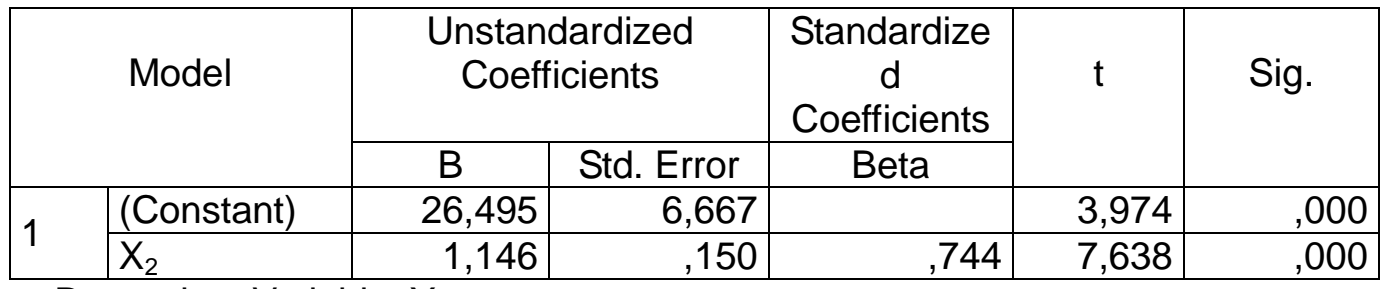

a. Dependent Variable: $\mathrm{Y}$

Dari Tabel.8 Coeficients menggambarkan persamaan regresi sederhana sebagai berikut :

\begin{tabular}{lll|}
$\mathrm{Y}$ & $=$ & $26,495+1,146 \mathrm{X}_{2}$ \\
\hline
\end{tabular}

Dimana : $\mathrm{X}_{2}=$ Rencana strategis

$\mathrm{Y}=$ Kinerja Unit Internal Audit \& Control

Konstanta sebesar 26,495, hal ini menandakan jika variabel rencana strategis $\left(\mathrm{X}_{2}\right)=0$ maka nilai kinerja Unit Internal Audit \& Control bernilai positif yaitu 26,495. Nilai Koefisien regresi variabel rencana strategis (b) bernilai positif yaitu 1,146 maka dapat diartikan setiap kenaikan 1\%,maka akan meningkatkan kinerja Unit Internal Audit \& Control 1,146.

Nilai $t$ hitung untuk variabel bebas rencana strategis 7,638 lebih besar dari t-tabel $1,679(7,638>1,679)$ artinya dapat disimpulkan bahwa rencana strategis berpengaruh signifikan terhadap kinerja Unit Internal Audit \& Control. Nilai Koefisien b positif, artinya jika rencana strategis naik maka kinerja Unit Internal Audit \& Control juga naik.

Nilai signifikansi $<0,05$ terlihat pada kolom Sig (Signifikan) pada tabel 8 Coeficients Sig. 0,000 atau lebih kecil dari nilai probabilitas $0,05(0,000<0,05)$. Maka dapat disimpulkan bahwa rencana strategis berpengaruh terhadap kinerja Unit Internal Audit \& Control. Nilai Koefisien B positif, artinya jika rencana strategis naik maka kinerja Unit Internal Audit \& Control juga naik.

Angka - angka yang terdapat dalam persamaan tersebut diperoleh dari tabel Coeffficients, secara lengkap dapat dilihat pada tabel 9 berikut :

Tabel 9 Nilai Koefisien Parsial dan Signifikansi

\begin{tabular}{|c|c|c|c|c|}
\hline \multirow{2}{*}{ Variabel } & \multicolumn{3}{|c|}{ Nilai } & \multirow{2}{*}{ Keterangan } \\
\cline { 2 - 4 } & t hitung & $\begin{array}{c}>\text { atau } \\
<\end{array}$ & $\mathrm{T}$ tabel & \\
\hline $\mathrm{X}_{1}$ & 4,587 & $>$ & 1,679 & Signifikan \\
\hline $\mathrm{X}_{2}$ & 7,638 & $>$ & 1,679 & Signifikan \\
\hline
\end{tabular}

\section{Uji Regresi Linier Berganda dengan Uji F}

Kemudian untuk mengetahui tingkat signifikan koefisien korelasi ganda dan pengujian signifikansi koefisien korelasi ganda dapat dilihat pada tabel Model Summary dan Anova (Analisis of Varians), yang hasil perhitungan menunjukan Jurnal Sekuritas, Vol.1, No.3, Maret 2018 
seperti dapat dilihat pada tabel 7 dan 8 dengan hasil output SPSS Versi 20.0 sebagai berikut :

Tabel 10 Tabel Koefisien Korelasi Ganda Model Summary ${ }^{b}$

\begin{tabular}{|l|r|r|r|r|}
\hline Model & $\mathrm{R}$ & $\mathrm{R}$ Square & $\begin{array}{c}\text { Adjusted R } \\
\text { Square }\end{array}$ & $\begin{array}{c}\text { Std. Error of } \\
\text { the Estimate }\end{array}$ \\
\hline 1 &, $794^{\mathrm{a}}$ &, 630 &, 614 & 6,575 \\
\hline
\end{tabular}

a. Predictors: (Constant), X2, X1

b. Dependent Variable: $Y$

Berdasarkan tabel 10 Model Summary bahwa besarnya pengaruh antara variabel Good Corporate Governane $\left(X_{1}\right)$ dan rencana strategis $\left(X_{2}\right)$ secara bersama- sama terhadap kinerja Unit Internal Audit \& Control $(\mathrm{Y})$ yang dihitung koefisien korelasi adalah 0,794 atau $\left(\mathrm{rx}_{1} \mathrm{x}_{2} \mathrm{y}=0,794\right)$. Hal ini menunjukan pengaruh yang kuat (tinggi). Sedangkan untuk kontribusi secara bersama-sama (Simultan) Good Corporate Governane dan rencana strategis terhadap kinerja Unit Internal Audit \& Control $(Y)$ atau koefisien diterminan $=r 2 \times 100 \%$ atau $0,630 \times 100 \%=63,0$ $\%$ sedangkan sisanya $37,0 \%$ dipengaruhi oleh variabel lain.

Tabel 11 di atas menyatakan bahwa hubungan antara variabel dependen dan independent signifikan sebesar 0,000 atau variabel independent berpengaruh terhadap variabel dependen. Nilai signifikansi $<0,05$ terlihat pada kolom Sig (Signifikan) pada tabel 4.11 Coeficients Sig. 0,000 atau lebih kecil dari nilai probabilitas $0,05(0,000<0,05)$.

Tabel 11 Tabel Signifikansi Koefisien ANOVA $^{a}$

\begin{tabular}{|c|c|c|c|c|c|c|}
\hline \multicolumn{2}{|c|}{ Model } & $\begin{array}{c}\text { Sum of } \\
\text { Squares }\end{array}$ & $\overline{d f}$ & $\begin{array}{l}\text { Mean } \\
\text { Square }\end{array}$ & $\bar{F}$ & Sig. \\
\hline \multirow{3}{*}{1} & Regression & 3386,937 & 2 & 1693,468 & 39,177 &, $000^{b}$ \\
\hline & Residual & 1988,410 & 46 & 43,226 & & \\
\hline & Total & 5375,347 & 48 & & & \\
\hline
\end{tabular}

a. Dependent Variable: $Y$

b. Predictors: (Constant), $X_{2}, X_{1}$

Hasilnya dapat disimpulkan bahwa Good Corporate Governane $\left(\mathrm{X}_{1}\right)$ dan rencana strategis $\left(X_{2}\right)$ secara bersama - sama memberikan pengaruh terhadap kinerja Unit Internal Audit \& Control $(\mathrm{Y})$ serta tingkat $\mathrm{F}$ hitung sebesar 39,177 atau $\mathrm{F}$ hitung $>$ tabel. Secara lebih tepat, nilai $F$ hitung dibandingkan dengan $F$ tabel dimana jika $F$ hitung $>F$ tabel maka secara simultan variabel-variabel independen berpengaruh signifikan terhadap variabel dependen.

Pada taraf $\alpha=0,05$ dengan derajat kebebasan pembilang/df1 $(k)=2$ (jumlah variabel independen) dan derajat kebebasan penyebut/df2 $(n-k-1)=46$, diperoleh nilai $F$ tabel 3,20. Dengan demikian, nilai $F$ hitung 39,177 lebih besar dari nilai $F$ tabel $(3,20)$ atau 39,177 > 3,20 secara lengkap dapat dilihat pada tabel berikut :

Tabel 12 Nilai Koefisien Parsial dan Signifikansi

\begin{tabular}{|c|c|c|c|c|}
\hline \multirow{2}{*}{ Variabel } & \multicolumn{3}{|c|}{ Nilai } & \multirow{2}{*}{ Keterangan } \\
\cline { 2 - 4 } & F hitung & $>$ atau $<$ & F tabel & \\
\hline 3 & 39,177 & $>$ & 3,20 & Signifikan \\
\hline
\end{tabular}


Berdasarkan hasil perhitungan tersebut dapat diinterpretasikan bahwa variabel Good Corporate Governane $\left(\mathrm{X}_{1}\right)$ dan rencana strategis $\left(\mathrm{X}_{2}\right)$ secara bersama-sama (simultan) mempengaruhi variabel kinerja Unit Internal Audit \& Control (Y).

Hasil persamaan garis regresi seperti dapat dilihat pada tabel 4.13 berdasarkan perhitungan hasil SPSS Versi 20.0 sebagai berikut :

Tabel 13 Tabel Garis Regresi

Coefficients $^{\mathrm{a}}$

\begin{tabular}{|c|c|c|c|c|c|c|c|c|}
\hline \multirow[t]{2}{*}{ Model } & \multicolumn{2}{|c|}{$\begin{array}{l}\text { Unstandardized } \\
\text { Coefficients }\end{array}$} & $\begin{array}{l}\text { Stand } \\
\text { Coeff }\end{array}$ & \multirow[t]{2}{*}{$\mathrm{t}$} & \multirow[t]{2}{*}{ Sig. } & \multicolumn{3}{|c|}{ Correlations } \\
\hline & $B$ & $\begin{array}{l}\text { Std. } \\
\text { Error }\end{array}$ & Beta & & & $\begin{array}{l}\text { Zero- } \\
\text { order }\end{array}$ & Partial & Part \\
\hline $\begin{array}{l}\text { (Consta } \\
\text { nt) }\end{array}$ & 11,847 & 7,764 & & 1,526 & , 134 & & & \\
\hline$X_{1}$ & ,326 & , 106 & ,303 & 3,079 & ,003 &, 556 & ,413 & ,276 \\
\hline$X_{2}$ & ,955 & ,151 & ,621 & 6,316 & ,000 & ,744 & 682 & ,566 \\
\hline
\end{tabular}

a. Dependent Variable: $Y$

Hasil analisis berdasarkan tabel 13 menunjukkan harga konstanta besarnya 11,847; harga koefisien $X_{1}$ besarnya 0,326 dan koefisien $X_{2}$ besarnya 0,955 . Korelasi partial untuk $X_{1}$ dan $X_{2}$ masing-masing 0,413 dan 0,682. Semua koefisien tersebut signifikan karena masing-masing signifikansinya 0,003 dan 0,000. Jadi persamaan garis regresinya adalah :

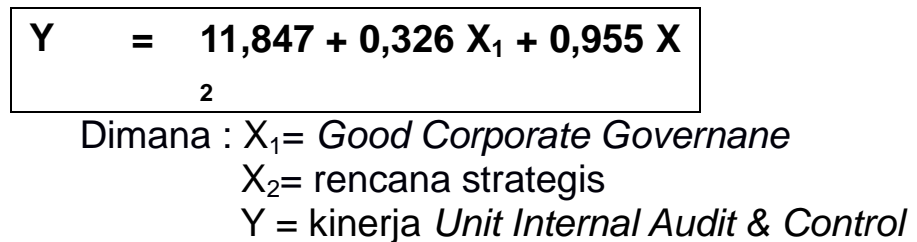

Berdasarkan table 13 di atas maka dapat disimpulkan bahwa hubungan antara Variabel Good Corporate Governance $\left(\mathrm{X}_{1}\right)$ dengan Kinerja Unit Internal Audit \& Control $(\mathrm{Y})$ berpengaruh rendah atau mempunyai pengaruh yang lemah $\left(\mathrm{rx}_{1} \mathrm{y}=\right.$ $0,326)$ dan mempunyai arah hubungan yang positif. Arah hubungan positif maksudnya adalah apabila Variabel Good Corporate Governance $\left(\mathrm{X}_{1}\right)$ naik $1 \%$ maka akan menaikkan Kinerja Unit Internal Audit \& Control $(Y)$ sebesar 32,60\%. Sebaliknya bila Variabel Good Corporate Governance $\left(X_{1}\right)$ turun $1 \%$ akan menurunkan Kinerja Unit Internal Audit \& Control $(Y)$ sebesar $32,60 \%$. Bila nilai $r x_{1} y$ $=0,326$ dikuadratkan maka akan didapat hasil $(0,326)^{2}=0,1062$ atau $10,62 \%$ Kinerja Unit Internal Audit \& Control (Y) dipengaruhi oleh Variabel Good Corporate Governance $\left(\mathrm{X}_{1}\right)$ sedangkan sisanya $89,38 \%$ dipengaruhi oleh variabel lain.

Hubungan antara variabel rencana strategis $\left(X_{2}\right)$ dengan kinerja Unit Internal Audit \& Control $(\mathrm{Y})$ berpengaruh sangat tinggi atau mempunyai pengaruh yang sangat kuat $\left(\mathrm{rx}_{2} \mathrm{y}=0,955\right)$ dan mempunyai arah hubungan yang positif. Arah hubungan positif maksudnya adalah apabila variabel rencana strategis $\left(\mathrm{X}_{2}\right)$ naik $1 \%$ maka akan menaikkan kinerja Unit Internal Audit \& Control (Y) sebesar 95,50\%. Sebaliknya bila Variabel Rencana Strategis $\left(\mathrm{X}_{2}\right)$ turun $1 \%$ akan menurunkan Kinerja Unit Internal Audit \& Control (Y) sebesar 95,50\%. Bila nilai $\mathrm{rx}_{2} \mathrm{y}=0,955$ dikuadratkan maka akan didapat hasil $(0,955)^{2}=0,9120$ atau $91,20 \%$ kinerja Unit Jurnal Sekuritas, Vol.1, No.3, Maret 2018 
Internal Audit \& Control $(\mathrm{Y})$ dipengaruhi oleh variabel rencana strategis $\left(\mathrm{X}_{2}\right)$ sedangkan sisanya $8,80 \%$ dipengaruhi oleh variabel lain.

\section{Pengujian Hipotesi}

Hasil penelitian dan hipotesis ini disajikan dalam matrik penelitian dibawah ini :

Tabel 14 Ringkasan Hasil Pengujian Hipotesis

\begin{tabular}{|c|l|c|}
\hline Kode & \multicolumn{1}{|c|}{ Hipotesis } & Hasil Penelitian \\
\hline $\mathrm{H}_{1}$ & $\begin{array}{l}\text { Diduga penerapan Good Corporate Governance } \\
\text { berpengaruh positif dan signifikan terhadap } \\
\text { peningkatan kinerja Unit Internal Audit \& Control. }\end{array}$ & Diterima \\
\hline $\mathrm{H}_{2}$ & $\begin{array}{l}\text { Diduga rencana strategis Unit Internal Audit \& } \\
\text { Control berpengaruh positif dan signifikan terhadap } \\
\text { peningkatan kinerja Unit Internal Audit \& Control. }\end{array}$ & Diterima \\
\hline $\mathrm{H}_{3}$ & $\begin{array}{l}\text { Diduga penerapan Good Corporate Governance dan } \\
\text { rencana strategis Unit Internal Audit \& Control secara } \\
\text { bersama-sama berpengaruh positif dan signifikan } \\
\text { terhadap peningkatan kinerja Unit Internal Audit \& } \\
\text { Control. }\end{array}$ & Diterima \\
\hline
\end{tabular}

\section{Pengaruh penerapan Good Corporate Governance terhadap peningkatan kinerja Unit Internal Audit \& Control}

Hipotesis pertama menyatakan diduga penerapan Good Corporate Governance berpengaruh positif dan signifikan terhadap peningkatan kinerja Unit Internal Audit \& Control PT. GMF Aero Asia. Hasil pengujian statistik menunjukan bahwa nilai koefisien regresi variabel Good Corporate Governance adalah 0,326. Nilai ini signifikan pada tingkat signifikansi 0,05 dengan $p$ value 0,003 . Hasil ini didukung oleh hasil perhitungan nilai $t$ hitung 4,587 $>\mathrm{t}$ tabel 1,679. Hal ini menunjukan bahwa Good Corporate Governance berpengaruh signifikan terhadap peningkatan kinerja Unit Internal Audit \& Control PT. GMF Aero Asia.

\section{Pengaruh rencana strategis terhadap peningkatan kinerja Unit Internal Audit \& Control}

Hipotesis kedua menyatakan diduga rencana strategis Unit Internal Audit \& Control berpengaruh positif dan signifikan terhadap kinerja Unit Internal Audit \& Control PT. GMF Aero Asia. Hasil Pengujian statistik menunjukan bahwa nilai koefisien regresi variabel Independensi adalah 0,955. Nilai ini signifikan pada tingkat signifikansi 0,05 dengan $p$ value 0,000 . Hasil ini didukung oleh hasil perhitungan nilai $t$ hitung $7,638>\mathrm{t}$ tabel 1,679 . Hal ini menunjukan bahwa rencana strategis berpengaruh signifikan terhadap kinerja Unit Internal Audit \& Control PT. GMF Aero Asia.

\section{Pengaruh penerapan Good Corporate Governance dan rencana strategis secara bersama-sama terhadap peningkatan kinerja Unit Internal Audit \& Control}

Hipotesis ketiga menyatakan diduga penerapan Good Corporate Governance dan rencana strategis Unit Internal Audit \& Control berpengaruh positif dan simultan terhadap peningkatan kinerja Unit Internal Audit \& Control. Hasil Pengujian statistik menunjukan bahwa Coeficients Sig. 0,000 atau lebih kecil dari nilai probabilitas $0,05(0,000<0,05)$. Hasil ini didukung oleh hasil perhitungan nilai $f$ 
hitung 39,177 <f tabel 3,20. Hal ini menunjukan bahwa penerapan good corporate governance dan rencana strategis Unit Internal Audit \& Control secara bersamasama (simultan) berpengaruh signifikan terhadap peningkatan kinerja Unit Internal Audit \& Control.

\section{Keterbatasan Penelitian}

Keterbatasan penelitian ini terkait dengan pengumpulan data serta pengembalian kuisioner yang memakan waktu cukup lama. Penulis menyadari keterbatasan ini disebabkan karena faktor diluar kemampuan penulis. Untuk itu penulis sangat menyadari bahwa penelitian ini tidak lepas dari kesalahan dan kekurangan, baik dari segi isi maupun cara penulisan.

\section{G. Kesimpulan dan Saran}

\section{Kesimpulan}

1. Terbukti benar bahwa ada pengaruh positif dan signifikan antara Good Corporate Governance terhadap kinerja Unit Internal Audit \& Control PT. GMF Aero Asia.

2. Terbukti benar bahwa ada pengaruh positif dan signifikan antara rencana strategis Unit Internal Audit \& Control terhadap kinerja Unit Internal Audit \& Control PT. GMF Aero Asia.

3. Terbukti benar bahwa ada pengaruh positif dan signifikan antara Good Corporate Governance dan rencana strategis Unit Internal Audit \& Control secara simultan terhadap kinerja Unit Internal Audit \& Control PT.GMF Aero Asia.

\section{Saran}

1. Perlu ditingkatkan upaya sosialisasi pelaksanaan mengenai nilai-nilai yang terkandung dalam kebijakan Good Corporate Governance kepada semua karyawan sehingga dapat menciptakan kondisi yang mendukung agar peran internal audit dapat terlaksana dengan baik di semua sektor.

2. Perlu ditingkatkan upaya sosialisai mengenai rencana strategis Unit Internal Audit \& Control bukan hanya di kalangan manajemen saja tapi di kalangan karyawan baik dalam lingkungan internal audit dan unit yang menggunakan jasa internal audit tersebut sehingga dapat mendukung peningkatan kinerja Unit Internal Audit \& Control dalam melaksanakan program-program yang berkesinambungan dan terintegrasi dengan visi dan misi perusahaan.

3. Perlu ditingkatkan upaya sosialisai mengenai penerapan nilai-nilai yang terkandung dalam kebijakan Good Corporate Governance dan aplikasi yang nyata mengenai rencana strategis Unit Internal Audit \& Control sehingga dapat mendukung peningkatan kinerja Unit Internal Audit \& Control PT. GMF Aero Asia.

4. Dalam rangka pengembangan hasil-hasil penelitian yang telah dicapai, disarankan agar dilakukan penelitian lanjutan dengan variabel bebas lainnya dengan informasi yang lebih lengkap, agar diperoleh hasil yang lebih baik. 


\section{H. Daftar Pustaka}

Alijoyo, F. A., dan Zaini, S., Komisaris Independen, Penggerak Praktik GCG di Perusahaan, PT Indeks, 2004.

Arafat, Wilson dan Mohamad Fajri M.P, Smart Strategy for 360 degree GCG. Jakarta : Sky Publisher, 2010.

Agoes, Sukrisno dan Estralita Trisnawati. Praktikum Audit. Seri 2. Jakarta : Salemba Empat. 2008.

Cresell, John W., Research Design : Qualitative, Quantitative and Mixed Methods Approaches. Edisi ke-2. India : Sage, 2003.

David, Fred R., Manajemen Strategis. Edisi ke-10, Jakarta : Salemba Empat. 2006.

Ghozali, Imam. Aplikasi Analisis Multivariate dengan Progam SPSS. Edisi 3. Badan Penerbit Universitas Diponegoro, Semarang. 2006.

Hamel, Gerry dan C.K. Prahalad. Kompetensi Masa Depan, Jakarta : PT. Binarupa Aksara, 1995 (terjemahan).

Ikatan Akuntan Indonesia., Standar Akuntansi Keuangan, Jakarta : Salemba Empat, 2010.

Komite Nasional Kebijakan Governance. Pedoman Umum Good Corporate Indonesia.(http://www.ecgi.org/codes/cg_2006_id.pdf, diakses pada tanggal 14 Mei 2012), 2006.

Kompas. Tingkat Pertumbuhan Ekonomi Yang Mencapai Titik Paling Rendah Sejak Masa Pemerintahan Soeharto, hlm.1, 31 Oktober, 2002.

Republik Indonesia. Keputusan Menteri Badan Usaha Milik Negara Republik Indonesia Nomor Kep-117/M-MBU/2002 tentang Penerapan Praktik Good Corporate Governance Pada BUMN. Sekretariat Negara. Jakarta. 2002.

Nardi Sunardi (2018) Analisis Risk Based Bank Rating (RBBR) Untuk Mengukur Tingkat Kesehatan Bank Syariah Di Indonesia, JIMF (Jurnal IImiah Manajemen Forkamma), Program Pascasarjana Universitas Pamulang, p-ISSN : 2598-9545, e-ISSN : 2599-171X, Vol 1, Vol.2, No.1, Februari 2018, Hal : 50 - 66.

Noor, Juliansyah., Metodologi Penelitian. Jakarta : Kencana Prenada Media Group. Cetakan ke-2, 2012.

Nowroozi, B. "Report on the Observance of Standards and Codes (ROSC), Corporate Governance Country Assessment," 2005 Policy Dialogue on Indonesia Corporate Governance, OECD, 2005.

Maksum, Azhar. Tinjauan Atas Good Corporate Governance Di Indonesia.Pidato 
Pengukuhan Jabatan Guru Besar Tetap Universitas Sumatera Utara. Medan : USU, 2005.

Mulyadi. Pemeriksaan Akuntan. Yogyakarta : Badan Penerbit STIE YKPN. 1992.

Porter, Micheal R., Strategi Bersaing : Tehnik Menganalisa Industri \& Pesaing. Jakarta : Erlangga. 2006.

Riduwan., Skala Pengukuran Variabel-Variabel Penelitian. Jakarta : Alfabeta. Cetakan ke-8, 2011.

Sugiono., Metode Penelitian Bisnis. Cetakan ke-4. Bandung : Alfabeta, 2012.

Sulistyanto, H.S., dan Wibisono, H., "Good Corporate Governance: Berhasilkah Diterapkan di Indonesia?” Jurnal Widya Warta, No. 2, Tahun XXVI, 2003. Sudharmono, Johny., Be G2G Good Coverned Company. Cetakan ke-2, Jakarta : PT. Gramedia. 2004.

Sawyer., L.B., Dittenhofer, M.A., Sawyer's Internal Auditing, The Practice of Modern Internal Auditing, The Institute of Internal Auditing, 4th ed. 1996.

Umar, Husein., Strategic Management in Action : Konsep, Teori dan Teknik Menganalisis Mamajemen Strategic Bussiness Unit Berdasarkan Konsep Micheal R. Porter, Fred R. David dan Wheelen Hunger, Jakarta : PT.Gramedia Pustaka Utama. 2005.

Tim Studi, Badan Pengawas Pasar Modal Dan Lembaga Keuangan Kementerian Keuangan Republik Indonesia. Kajian Tentang Pedoman Good Corporate Governance Di Negara-Negara Anggota ACMF.Jakarta : Kementerian Keuangan Republik Indonesia, 2010.

Tugiman, Hiro. Standar Profesional Audit Internal. Jakarta : Kanisius. 2010

Warsono, Sonny dan Amalia, Fitri et al., CGCG'S UGM, Cetakan ke-1, Yogjakarta : CGCG UGM, 2010.

Ward, John dan Joe Peppard. Strategic Planning for Informatiom System. John Wiley, 2007.

Williams, Chuck. Management. South-Western Cengage Learning : 2008.

Zagloel, T. Yuri dan Yadrifil et al., Perencanaan Strategi Dalam Upaya Menyelaraskan Tujuan Organisasi Dan Tujuan Karyawan Dengan 